BIOMEDICAL AND BIOSOCIAL ANTHROPOLOGY
$\begin{gathered}\text { Official Journal of the International Academy } \\ \text { of Integrative Anthropology } \\ \text { journal homepage: http://bba-journal.com }\end{gathered}$

\title{
Investigation of 4-methyl-2.2-dioxo-1h-2 $\lambda^{6}, 1$-benzothiazine-3- carboxamide derivative influence on the biochemical markers of gastric mucosa in rats
}

Malchenko O. V., Voloshchuk N. I., Pentiuk N. O.

National Pirogov Memorial Medical University, Vinnytsya, Ukraine

\section{ARTICLE INFO}

Received: 4 November 2020

Accepted: 4 December 2020

UDC: $615.015 .35: 615.276: 547.728 .2$

CORRESPONDING AUTHOR

e-mail: voloshchuk@vnmu.edu.ua Voloshchuk N. I.

\begin{abstract}
Non-steroidal anti-inflammatory drugs occupy a leading position in the pharmaceutical market, but their class-specific side effect (ulcerogenic action) significantly limits their widespread use. The N-(4-methoxybenzyl)-4-methyl-2, 2-dioxo-1H-2 $\lambda^{6}, 1-$ benzothiazine-3-carboxamide derivative (compound NI-9) showed a pronounced analgesic effect in various models of pain syndromes. The aim of the study was to determine the effect of a new original derivative of 4-methyl-2.2-dixo-1H-2 $\lambda^{6}, 1$ benzothiazine-3-carboxylic acid on the macroscopic state and biochemical parameters of the gastric mucosa of rats. The study was performed on 51 male Wistar rats. Compound $\mathrm{NI}-9$ and the reference drug meloxicam were administered intragastrically once daily for 28 days at doses of 3 and $5 \mathrm{mg} / \mathrm{kg}$, corresponding to their ED50 analgesic activity. Macroscopic indicators of GM damage, glycosaminoglycan content, phospholipid profile, level of MDA and CGP, as well as nitrates and nitrites and $\mathrm{H}_{2} \mathrm{~S}$ were determined. The results were processed in the program STATISTICA 10.0 using non-parametric methods. The results showed that the carboxamide derivative was safer for the stomach because the ulcer index of compound NI-9 was 1.73 times lower than that of meloxicam. The damaging effect of the compound was more pronounced at the pre-epithelial and epithelial levels of GM protection, while the post-epithelial level (production of vasodilating molecules $\mathrm{NO}$ and $\mathrm{H}_{2} \mathrm{~S}$ ) was practically unaffected by this derivative, unlike meloxicam, which caused damage at all levels of protection. The obtained data supplement the data on the pharmacodynamics of the 4-methyl-2.2-dixo- $1 \mathrm{H}-2 \lambda^{6}, 1$ benzothiazine-3-carboxylic acid derivative and determine the expediency of its further studies as a potential non-opioid analgesic.

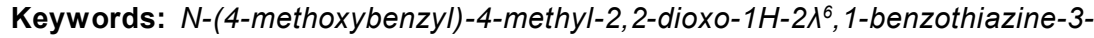
carboxamide, ulcerogenic effect, gastric mucosa, biochemical markers, oxidative stress, nitrogen monoxide, hydrogen sulfide.
\end{abstract}

\section{Introduction}

Analysis of the pharmaceutical market of drugs shows that in the arsenal of modern non-narcotic drugs with pronounced analgesic and anti-inflammatory activity an important place belongs to the derivatives of carboxylic acids [9, 16]. According to the chemical structure, drugs of this class can be divided into several groups: first of all derivatives of well-known salicylic acid (aspirin, etc.), derivatives of anthranilic and 2-aminonicotinic acids, which have structural similarity to salicylic acid (mefenamic, flufenamic acid, etc.). Particularly popular analgesics have been developed based on phenylacetic acid (diclofenac). In addition, the largest group of drugs approved for use as analgesics were 2-phenylpropionic acids (naproxen, dexketoprofen, ibuprofen). Separate mention should be made of derivatives of succinic acid (fenbufen and suxibuzone), hetarylic acid (etodolac and ketorolac), and hetarylacetic acid (indomethacin, sulindac). All of these drugs are the most common group of over-the-counter drugs used by more than 30 million people worldwide, despite the well-known class-specific gastrointestinal side effects (GIs) associated with the free carboxyl group. However, there is no doubt that the presence of an acid fragment (or chemical group that can be easily converted to such in vivo), often has a very positive effect on the 
biological properties of a molecule [18]. Therefore, carboxylic acids are always of particular interest for the search for promising analgesics [22], and their possible side effects can be eliminated by subsequent chemical transformations into labile non-acidic groups or special conditions of their introduction [12].

Given the above, our attention was drawn to new derivatives of 4-methyl-2.2-dixo-1 $\mathrm{H}-2 \lambda^{6}$.1-benzothiazine-3carboxylic acid, in particular N-4-methoxybenzyl-amide - a substituted derivative (compound with laboratory code NI9), which demonstrated high anti-inflammatory and analgesic activity in various models of pain perception [21]. Because this compound is derived from a bioisoteric substitution in the molecule of oxycamins, known nonsteroidal anti-inflammatory drugs (NSAIDs), in addition to establishing its pharmacological activity, it was necessary to conduct a study of the safety of this molecule in the gastrointestinal tract.

The aim of the study was to determine the effect of a new original derivative of 4-methyl-2.2-dixo-1H-2 $\lambda^{6} .1$ benzothiazine-3-carboxylic acid on the macroscopic state and biochemical parameters of the gastric mucosa of rats.

\section{Materials and methods}

The research was performed on the basis of a research laboratory for preclinical study of pharmacological substances of the Department of Pharmacology of National Pirogov Memorial Medical University, Vinnytsya (certificate of the Ministry of Health on technical competence №030/ 18 dated November 1, 2018, valid until October 31, 2023). The study included 51 male Wistar rats obtained from the vivarium of the Institute of Pharmacology and Toxicology of the Academy of Medical Sciences of Ukraine. During the experiment, the animals were kept in standard conditions (day/night regime 12/12 and access to water and food ad libitum), according to the norms. The research met all the necessary requirements for humane treatment of experimental animals and complied with the rules of the "European Convention for the Protection of Vertebrate Animals Used for Experimental and Other Scientific Purposes" (Strasbourg, 1986) and current laws of Ukraine. Compound NI-9 and the most chemically similar drug meloxicam were administered intragastrically once daily for 28 days at a conditionally effective antinociceptive dose (ED50) of 3 and $5 \mathrm{mg} / \mathrm{kg}$, respectively. Evaluation of ulcerogenic action of compounds by macroscopic signs was performed after euthanasia of animals by cervical dislocation, followed by dissection of the abdominal cavity, removed the stomach, cut at low curvature, washed with saline and assessed the degree of damage to the gastric mucosa. 0 - no damage; 0.5 - hyperemia; 1 - single minor injuries; 2 - multiple injuries (erosions, punctate hemorrhages); 3 - significant and multiple damage to GM; 4 - serious injuries (massive hemorrhages, erosions, perforations). The multiplicity of damage was estimated as the average number of ulcers per animal, the severity - was calculated as the average sum of the products - (the number of ulcers $x$ severity). Ulcer index (UI) was calculated by the formula [19]: UI = arithmetic mean of the sum of points $\mathrm{x} \%$ of animals with ulcers / 100 .

During biochemical studies, GM was isolated, perfused with cold $1.15 \% \mathrm{KCl}$ solution and homogenized at 3000 rpm (Teflon glass) in $1.15 \% \mathrm{KCl}$ medium (1: 3 ratio). The protein content in the postnuclear supernatant was assessed by the microbiuret method [10], the level of malonic dialdehyde (MDA) - by reaction with thiobarbituric acid [23], carbonyl groups of proteins (CGP) - by reaction with 2,4-dinitrophenylhydrazine [20]. The level of glycosaminoglycans (GAG) was determined by the level of hexosamines by reaction with para-dimethylbenzaldehyde [14]. The content of phospholipid fractions was determined by thin layer chromatography on silica gel L5 / 40 (Chemapol, Czech Republic) using chloroform-methanolwater solvents in the ratio 65: 30: 5 (by volume). The phospholipid fractions of phosphatidylcholine $(\mathrm{PH})$, lysophosphatidylcholine (LPH), phosphatidylethanolamine $(P E)$ were identified by qualitative reactions and by $R f$ values, and their quantitative content was determined after chromatography by reaction with phosphorus-vanillin reagent.

The content of nitrites and nitrates was determined by reaction with Gris reagent [11]. The content of $\mathrm{H}_{2} \mathrm{~S}$ in blood serum was determined by spectrophotometric method, which is based on the formation of thionine in the reaction between sulfide anion and para-phenylenediamine hydrochloride in an acidic environment in the presence of iron (III) ions [29].

Statistical processing of the obtained results was performed by methods of variation statistics using the software package STATISTICA 10.0 with the calculation of the mean value, standard error of the mean, confidence interval $(p)$ and non-parametric Mana-Whitney test. Differences were considered plausible in the case of $p<0.05$.

\section{Results}

Our results showed that long-term administration of the compound under study did not cause changes in eating behavior, appearance of rats and did not lead to death. Weight gain in animals administered NI-9 was $11.3 \pm 1.2 \%$, which was almost the same as in the meloxicam group $(11.4 \pm 0.6 \%)$. Body weight in control rats increased by $13.7 \pm 1.5 \%$ during this period, but these differences were not significant. Analyzing the macroscopic picture of the gastric mucosa, it should be noted that the compound NI-9 caused less pronounced damage to GM than the comparison drug. Its long-term (28-day) administration caused ulcerative lesions was observed in only $71.4 \%$ of animals against $85.7 \%$ in the group administered meloxicam. The multiplicity of ulcers on the background of the introduction of a derivative of 4-methyl-2,2-dixo-1 $\mathrm{H}$ $2 \lambda^{6}$,1-benzothiazine-3-carboxylic acid was $54.2 \%$, and the 
severity was $30.8 \%$ lower than that of the reference drug (Table 1). The ulcer index of compound NI-9 was 1.73 times lower than that of meloxicam.

The next step was to evaluate changes in biochemical markers of gastric mucosa in rats against NI-9 and meloxicam compared to control animals. The results showed that both compounds had a negative effect on the production of mucus in the stomach, as evidenced by a decrease in the content of glycosaminoglycans in GM (Table 2). However, against the background of the carboxamide derivative, the decrease in this indicator was $11.2 \%$ relative to the control, while in animals administered meloxicam, this indicator decreased more markedly (by $21.1 \%, p<0.05$ ).

It is known that the basis of ulcerogenic action of NSAIDs is the development of oxidative stress in the gastric mucosa. Therefore, we further evaluated the changes in the products of lipid and protein peroxidation against the background of the action of the compounds studied. The results shown in Table 2 showed that NI-9 significantly increased the content of MDA and CGP in GM by $2.7 \%$ and $14.3 \%$ compared to control rats, but this increase was $12.7 \%$ and $11.9 \%$ lower than in the background introduction of a reference drug $(p<0.05)$.

Under the conditions of the experiment, the phospholipid spectrum of GM cell membranes also changed. Compound NI-9 caused a statistically significant decrease in the content of total phospholipids and phosphatidylcholine (by $13.5 \%$ and $29.9 \%$, respectively $\mathrm{p}<0.05$ ), with a simultaneous increase in the content of lysophosphatidylcholine and phosphatidylethanolamine by $22.2 \%$ and $19.0 \%$, respectively, $\mathrm{p}<0.05)$. These values were smaller than the changes that meloxicam caused, but this difference did not reach statistically significant values (Table 3 ).

It is well known that violations of the integrity of the gastric mucosa on the background of NSAIDs are disorders of microcirculation, which lead to a prevalence of vasoconstrictor effects and reduced production of vasodilating molecules, in particular, nitrogen monoxide. Therefore, we further evaluated the total content of nitrates and nitrites in the GM under the conditions of administration of the compound NI-9 in comparison with meloxicam (Table 4).

Studies have shown that the use of a typical representative of the group of selective PTGS2 inhibitors meloxicam is accompanied by a significant reduction of $\mathrm{NO}_{2}{ }^{-} \mathrm{NO}_{3}{ }^{-}$in $\mathrm{GM}$ by $20.6 \%$, respectively, while 28 -day administration of $\mathrm{Nl}-9$ - did not change the content of these molecules in the stomach. A similar trend was found for the content of hydrogen sulfide - a vasoactive molecule that regulates the integrity of $\mathrm{GM}$ and plays an important protective role in NSAID-induced gastropathies [26]. It was found that the new derivative of benzothiazine-3-carboxylic acid had no depressant effect on the content of $\mathrm{H}_{2} \mathrm{~S}$ in $\mathrm{CO}$, but on the contrary, showed a tendency to increase its content (by $3.57 \%$ ) compared with the control. At the same
Table 1. Indicators of gastrotoxicity of the compound NI-9 and meloxicam under conditions of long-term administration in rats $(\mathrm{M} \pm \mathrm{m}$, $\mathrm{n}=10)$.

\begin{tabular}{|l|c|c|c|}
\hline & Plurality & Difficulty & $\begin{array}{c}\text { Ulcerative } \\
\text { index }\end{array}$ \\
\hline Control & 0 & 0 & 0 \\
\hline Compound Nl-9 $(3 \mathrm{mg} / \mathrm{kg})$ & $1.143 \pm 0,204^{*}$ & $0.857 \pm 0.161^{*}$ & 0.642 \\
\hline Meloxicam $(5 \mathrm{mg} / \mathrm{kg})$ & $2.429 \pm 0,371$ & $1.286 \pm 0,186$ & 1.112 \\
\hline
\end{tabular}

Note: ${ }^{*}$ - statistically significant differences $(p<0.05)$ relative to meloxicam.

Table 2. The effect of NI-9 compound and meloxicam on the level of lipid and protein peroxidation products in intact rats $\mathrm{GM}(\mathrm{M} \pm \mathrm{m}$, $\mathrm{n}=7$ ).

\begin{tabular}{|c|c|c|c|c|}
\hline $\begin{array}{c}\text { № in } \\
\text { order }\end{array}$ & Groups of rats & $\begin{array}{c}\mathrm{GAG}, \\
\mathrm{mg} / \mathrm{g} \text { tissue }\end{array}$ & $\begin{array}{c}\mathrm{MDA}, \\
\mathrm{nmol} / \mathrm{mg} \\
\text { protein }\end{array}$ & $\begin{array}{c}\mathrm{CGP}, \\
\text { nmol/mg } \\
\text { protein }\end{array}$ \\
\hline 1 & Control & $4.047 \pm 0,113$ & $6.485 \pm 0.225$ & $2.430 \pm 0.090^{!}$ \\
\hline 2 & Meloxicam & $3.251 \pm 0.102^{*}$ & $9.236 \pm 0.304^{*}$ & $3.174 \pm 0.131^{*}$ \\
\hline 3 & Compound $\mathrm{N}-9$ & $3.660 \pm 0.139^{* *}$ & $8.089 \pm 0.371^{\text {*\# }}$ & $2.789 \pm 0.083^{\text {*\# }}$ \\
\hline
\end{tabular}

Notes: ${ }^{*}-p<0.05$ relatively intact animals; ${ }^{*}-p<0.05$ between groups of animals treated with meloxicam and compound NI-9.

Table 3. Effect of NI-9 compound and meloxicam on the phospholipid spectrum of intact rats $\mathrm{GM}(\mathrm{M} \pm \mathrm{m}, \mathrm{n}=7)$.

\begin{tabular}{|c|c|c|c|c|}
\hline \multirow{2}{*}{$\begin{array}{c}\text { № in } \\
\text { order }\end{array}$} & $\begin{array}{c}\text { Phospholipid } \\
\text { level, } \mu \mathrm{g} / \mathrm{mg} \\
\text { protein }\end{array}$ & \multicolumn{3}{|c|}{ Groups of rats } \\
\cline { 3 - 5 } & Control & Meloxicam & Compound N1-9 \\
\hline 1 & General PL & $274.8 \pm 8.302$ & $222.3 \pm 7.800^{*}$ & $238.1 \pm 5.771^{*}$ \\
\hline 2 & $\mathrm{PH}$ & $119.7 \pm 5.906$ & $78.59 \pm 4.212^{*}$ & $84.11 \pm 3.892^{*}$ \\
\hline 3 & $\mathrm{PE}$ & $64.80 \pm 4.837$ & $80.40 \pm 4.521^{*}$ & $79.20 \pm 4.351^{*}$ \\
\hline 4 & $\mathrm{LPH}$ & $18.91 \pm 1.219$ & $23.40 \pm 1.285^{*}$ & $22.49 \pm 1.088^{*}$ \\
\hline
\end{tabular}

Note: ${ }^{*}-p<0.05$ relatively intact animals.

Table 4. The effect of NI-9 compound and meloxicam on the content of hydrogen sulfide and metabolites of nitrogen monoxide in intact rats $\mathrm{GM}(\mathrm{M} \pm \mathrm{m}, \mathrm{n}=7)$.

\begin{tabular}{|c|c|c|c|}
\hline $\begin{array}{c}\text { № in } \\
\text { order }\end{array}$ & Groups of rats & $\begin{array}{c}\mathrm{H}_{2} \mathrm{~S}, \mathrm{nmol} / \mathrm{mg} \\
\text { protein }\end{array}$ & $\begin{array}{c}\mathrm{NO}_{2}^{-}+\mathrm{NO}_{3}, \mathrm{nmol} / \mathrm{g} \text { of } \\
\text { tissue }\end{array}$ \\
\hline 1 & Control & $1.637 \pm 0.085$ & $2.103 \pm 0.147$ \\
\hline 2 & Meloxicam & $1.390 \pm 0,065^{*}$ & $1.700 \pm 0.148^{*}$ \\
\hline 3 & Compound NI-9 & $1.740 \pm 0.093^{\#}$ & $2.200 \pm 0.166^{\#}$ \\
\hline
\end{tabular}

Notes: ${ }^{*}-p<0.05$ relative to intact animals; ${ }^{\#}-p<0.05$ between groups of animals treated with meloxicam and compound NI-9.

time, meloxicam probably (by $17.3 \%$ ) reduced the content of this vasodilator in the gastric mucosa.

\section{Discussion}

Studies have confirmed that the new original derivative of N-(4-methoxybenzyl)-4-methyl-2.2-dixo-1H-2 $\lambda^{6} .1$ benzothiazine-3-carboxylic acid - a compound with the laboratory code NI-9 - has a sufficient safety profile, and in its effect on the gastric mucosa is superior to the nearest chemical structure of the drug meloxicam. This is evidenced by a lower ulcer index of this compound with prolonged administration to the body in an average therapeutic dose of ED50 (3 mg / kg). 
Specific gastric lesions, which include non-ulcer dyspepsia, epigastric pain, anorexia, esophagitis, constipation and diarrhea, erosions and ulcers in the stomach and duodenum, as well as perforation, have become clinically defined and are now referred to as "NSAID-gastropathy" [1, 2, 15, 17, 27]. These lesions mainly affect the stomach and duodenum, although NSAIDs can affect any part of the gastrointestinal tract, from the esophagus to the colon. The largest lesions are ketorolac, aceclofenac, celecoxib, desketoprofen, meloxicam, nimesulide and rofecoxib. The risk of bleeding was increased in patients with a history of peptic ulcer disease and/or gastrointestinal bleeding and using antiplatelet agents.

Nonsteroidal anti-inflammatory drugs are usually able to disrupt the integrity of the gastric mucosa due to the impact on different levels of its protection [6]. The main preepithelial (mucosal bicarbonate-phospholipid "barrier", creating cells of the superficial epithelium of the stomach, which produce mucus, bicarbonates, phospholipids, peptides, heat shock proteins, and some other biologically active substances that neutralize and disperse gastric lumen to mucous cells); epithelial (resistance of the surface of epithelial cells and intercellular contacts to the back diffusion of hydrogen ions and hydrophobic properties of the mucous membrane, which contribute to the "repulsion" of hydrochloric acid, as well as the high proliferative capacity of epithelial cells) and postepithelial, which are provided by vasoactive molecules. The most wellknown components in this regard are prostaglandins (PG) - PGE2 and PGI2. According to modern ideas, their protective effect on the central nervous system is realized through several mechanisms: inhibition of hydrochloric acid in the stomach, increased secretion of mucus and bicarbonate, and PGI2 (prostacyclin), is a powerful vasodilator that provides normal blood circulation in the gastric mucosa, stabilizes the membranes of mast cells and lysosomes, inhibits the production of free radicals and enzymes by neutrophils, regulation of vascular endothelium.

Microcirculation disorders due to hyperproduction of vasoconstrictor and decrease in the content of vasodilating molecules play an important role in the biochemical mechanisms of development of NSAID-induced gastric lesions. The literature describes a number of biologically active substances of endothelial and plasma origin, which regulate vascular tone. Among these mediators, in addition to prostaglandins, oxygen free radicals, nitric oxide, and $\mathrm{H}_{2} \mathrm{~S}$ have recently been identified $[4,13,24,25,28]$. Therefore, the search for and research of new drugs that have anti-inflammatory and analgesic activity, it is

\section{References}

[1] Blackler, R., Bolla, M., Syer, S. Bolla, M., Ongini, E., \& Wallace, J. L. (2012). Gastrointestinal-sparing effects of novel NSAIDs in rats with compromised mucosal defence. PLoS One, 7(4), e35196. doi: 10.1371/journal.pone.0035196

[2] Bondarenko, O. O., Ahibalov, O. M. Dyadik, O. O., \& Steshenko, necessary to establish their safety in the gastrointestinal tract.

The results obtained in our study showed that among the molecular mechanisms of modulation of the GM on the background of the compound $\mathrm{NI}-9$, we can note its negative impact on the processes of lipid and protein peroxidation, mucus production, phospholipid spectrum of GM cell membranes, the severity of which meloxicam. In addition, it should be noted that in contrast to the latter, the derivative of benzothiazine-3-carboxylic acid has no inhibitory effect on the production of nitrogen monoxide, and also tends to increase the content of hydrogen sulfide in the GM, which may have been one of the explanations for its greater stomach safety.

The reason for such differences, in our opinion, may be the peculiarities of the chemical structure of this molecule. It is known from the literature that one of the prerequisites for the safety of NSAIDs in the gastrointestinal tract is a selective effect on PTGS2 and the absence or minimal effect on PTGS1. Meloxicam, as the closest in structure to NSAIDs, belongs to a group of drugs that mainly affect the inducible isoform of cyclooxygenase [3, 7]. The drug binds to the upper part of the PTGS2 channel and has a balanced PTGS2 selectivity profile. Other highly selective PTGS2coxib inhibitors also do not have the ability to damage the stomach, however, they bind to the lateral pocket of the PTGS2 channel and inhibit thromboxane less, which explains the increased risk of thromboembolic complications if long-term use [5]. It is possible that the $\mathrm{N}$ (4-methoxybenzyl)-4-methyl-2.2-dixo-1H-2 $\lambda^{6} .1$ benzothiazine-3-carboxylic acid derivative studied has its own interactions with molecular markers of inflammation and pain. However, for final conclusions it is necessary to conduct additional research in this direction.

\section{Conclusion}

The data obtained show, that compound N-(4methoxybenzyl) -4-methyl-2.2-dixo-1H-2 $\lambda^{6}$.1-benzothiazine3 -carboxylic acid has a high degree of safety in relation to the gastrointestinal tract in intact, which exceeds reference preparation meloxicam. This difference is mainly due to a less pronounced depressant effect on the postpithelial mechanism of protection of the gastric mucosa, namely, the production of vasodilating molecules in the central nervous system. The results supplement the data on the pharmacodynamics of the 4-methyl-2.2-dixo-1H-2 $\lambda^{6} .1$ benzothiazine-3-carboxylic acid derivative and determine the feasibility of its further studies as a potential non-opioid analgesic.

А.О. (2020). Особливості ведення хворих з НПЗП-індукованою гастропатією: від розуміння механізмів розвитку до стратегії профрілактики та лікування. Ризики короткочасного застосування нестероїдних протизапальних препаратів. Частина I [Feachures of management of patients 
with NSAID-induced gastropathy: from understanding the mechanisms of development to the strategy of prevention and treatment. Risks of short-term use of nonsteroidal antiinflammatory drugs. Part I]. Сучасна гастроентерологія Modern gastroenterology, (4), 39-50. doi: 10.30978/MG-20204-39

[3] Burukoglu, D., Baycu, C., Taplamacioglu, F., Sahin, E., \& Bektur, E. (2016). Effects of nonsteroidal anti-inflammatory meloxicam on stomach, kidney, and liver of rats. Toxicol Ind Health., 32(6), 980-986. doi: 10.1177/0748233714538484

[4] Chan, M. V., \& Wallace, J. L. (2013). Hydrogen sulfide-based therapeutics and gastrointestinal diseases: translating physiology to treatments. Am. J. Physiol. Gastrointest. Liver Physiol, 305(7), G467-473. doi: 10.1152/ajpgi.00169.2013

[5] Fidahic, M., Kadic, A. J., Radic, M. \& Puljak, L. (2017). Celecoxib for rheumatoid arthritis. Cochrane Database Syst Rev, 6(6), CD012095. doi: 10.1002/14651858.CD012095.pub2

[6] Garcia-Rayado, G., Navarro, M., \& Lanas, A. (2018). NSAID induced gastrointestinal damage and designing Gl-sparing NSAIDs. Expert. Rev. Clin. Pharmacol, (10), 1031-1043. doi: 10.1080/17512433.2018.1516143

[7] Hunt, R., Lazebnik, L. B, Marakhouski, Y. C., Manuc, M., Gn, R., Aye, K. S., ... \& Garg, A. (2018). International Consensus on Guiding Recommendations for Management of Patients with Nonsteroidal Antiinflammatory Drugs Induced GastropathyICON-G. Euroasian Journal of Hepato-Gastroenterology, 8(2), 148-151. doi: 10.5005/jp-journals-10018-1281

[8] Keitz, М. (1975). Техника липидологии [Technique of lipidology]. М.: Мир - M.: Mir.

[9] Kleemann, A., Engel, J., Kutscher, B., \& Reichert, D. (2008). Pharmaceutical Substances: Syntheses, Patents, Applications of the Most Relevant APIs, 5th ed. Thieme: Stuttgart, Germany.

[10] Kochetov, G. A. (1980). Практическое руководство по энзимологии [A practival guide to enzymology]. М.: Высшая школа - M.: Vishshaya shkola.

[11] Korenman, I. М. (1975). Методы определения органических соединений [Methods for determination of organic compounds]. М.: Химия - М.: Himia.

[12] Kuznetsov, S. G., Chigareva, S. M., \& Ramsh, S. M. (1981). Prodrugs. Chemical aspect. Results Sci. Technol. VINITI. Ser. Org. Chem, (19), 1-176.

[13] Lowicka, E., \& Beltowski, J. (2007). Hydrogen sulfide (H2S) the third gas of interest for pharmacologists. Pharmacological reports, (59), 4-24.

[14] Ludowieg, J., \& Benmaman, D. (1967). Colorimetric differentiation of hexosamines. Anal. Biochem., 19(1), 80-88.

[15] Moore, R. A., Derry, S., Phillips, C. J., \& McQuay, H. J. (2006). Nonsteroidal anti-inflammatory drugs (NSAIDs), cyxlooxygenase-2 selective inhibitors (coxibs) and gastrointestinal harm: review of clinical trials and clinical practice. BMC Musculoskeletal Disorders, (7), 79-91. doi: 10.1186/1471-2474-7-79

[16] O'Neil, M. J., Heckelman, P. E.; Koch, C. B., \& Roman, K. J. (2006). The Merck Index: An Encyclopedia of Chemicals, Drugs, and Biologicals, 14th ed. Merck and Co., Inc.: Whitehouse Station, NJ, USA.

[17] Palileo, C., \& Kaunitz, J. D. (2011). Gastrointestinal defense mechanisms. Curr. Opin. Gastroenterol., 27(6), 543-548. doi: 10.1097/MOG.0b013e32834b3fcb

[18] Proschak, E., Heitel, P., Kalinowsky, L., \& Merk, D. (2017). Opportunities and challenges for fatty acid mimetics in drug discovery. J. Med. Chem, (60), 5235-5266. doi: 10.1021/ acs.jmedchem.6b01287

[19] Stefanov, O. V. (red). (2001). Доклінічні дослідження лікарських засобів: Метод. рекомендації [Preclinical studies of drugs: Method. Recommendations]. K.: VD "Avitsena".

[20] Shevchuk, S. V., Pentuk, O. O., Musin, R. A., \& Zaichko, N. V. (2003). Патент України 58110A [Patent of Ukraine 58110A]. Київ: державне патентне видавництво - Kyiv: State Patent Publishing House.

[21] Ukrainets, I. V., Hamza, G. M., Burian, A. A., Voloshchuk, N. I., Malchenko, O. V., Shishkina, S. V., ... \& Sim, G. (2018). Molecular Conformations and Biological Activity of N-Hetaryl(aryl)alkyl4-methyl-2,2-dioxo-1 H-2 $\lambda^{6}$, 1-benzothiazine-3-carboxamides. Sci. Pharm, (86), 50. doi: 10.3390/scipharm86040050

[22] Ukrainets, I. V., Mospanova, E. V., Savchenkova, L. V., \& Yankovich, S. I. (2011). 4-Hydroxy-2-quinolones. 195. Synthesis of novel, potential analgesics based on 4(hetarylmethyl)amino-2-oxo-1,2-dihydroquinoline-3-carboxylic acids. Chem. Heterocycl. Compd., (47), 67-73.

[23] Vladimirov, Yu. A., \&Archakov A. І. (1972). Перекисное окисление липидов в биологических мембранах [Lipid peroxidation in biological membranes]. М.: Наука - М.: Nauka.

[24] Voloshchuk, N., Taran, I., Pashynska, O., Melnyk, A., \& Magdebura, S. (2020). The role of hydrogen sulfide in gastrointestinal tract functioning. Current Issues in Pharmacy and Medical Sciences, 1(33), 45-50. doi: 10.2478/cipms-20200009

[25] Voloshchuk, N. I., Taran, I. V., \& Mel'nik, A. V. (2015). Influence of diclofenac sodium on biochemical indicators of stomach mucosa conditions against the background of excess and deficiency of hydrogen sulfide in rats. The Science Advanced, (01), 36-40.

[26] Voloshchuk, N. I., Taran, I. V., \& Mel'nik, A. V. (2015). Vascular mechanism in the diclophenac induced gastrotoxicity: the association with the level of hydrogen sulfide. Curierul medical, 58(1), 7-11.

[27] Victorov, O. Р. \& Kashuba, O. V. (2010). Проблеми та перспективи отримання інформації пропобічні реакції, спричинені нестероїдними протизапальними препаратами, шляхом анонімного опитування пацієнтів (погляд на проблемy) [Problems and prospects of obtaining information on side effects caused by nonsteroidal anti-inflammatory drugs by anonymous survey of patients (view of the problem)]. Український медичний часопис - Ukrainian medical journal, 6(80), 111-114.

[28] Wallace J. L., Vaughan, D., Dicay, M., MacNaughton, W. K., \& de Nucci, G. (2018). Hydrogen Sulfide-Releasing Therapeutics: Translation to the Clinic. Antioxid Redox Signal, 28(16), 533-1540. doi: 10.1089/ars.2017.7068

[29] Zaichko, N. V., Pentuk, N. O., \& Melnyk, A. V. (2010). Патент України 52136 [Patent of Ukraine 52136]. Київ: державне патентне видавництво - Київ: державне патентне видавництво. 